\title{
Biological invasions in the aquatic ecosystems of Europe as a threat to biodiversity
}

\author{
Katarzyna Wołczuk, Michał Mięsikowski, Karolina Jarzynka, Bogdana Wilczyńska \\ Laboratory of Histology and Embryology of Vertebrates, Institute of Ecology and Environment Protection, Depart- \\ ment of Biology and Earth Sciences, \\ Nicolaus Copernicus University, Gagarina 9, 87-100 Toruń, Poland \\ e-mail: katkoz@umk.pl
}

\begin{abstract}
In recent years biological invasions have become a serious ecological and socio-economic problem for many countries. Invasions are promoted by anthropogenic activity which is broadly understood as well as the instability of ecosystems. It carries a number of threats, often difficult to predict. The effects of invasion are long-term and occur on many levels of life. They can very often contribute to the extinction of native species, thus reducing biodiversity.

According to the concept of sustainable development, the protection of biodiversity, and thus the prevention of biological invasions, is a necessary condition both to maintain the variety of nature, and to further the economic development of each country.
\end{abstract}

Key words: invasive species, alien species, introduction, spread.

\section{Introduction}

In recent decades human activity has became a major factor affecting the state of biodiversity of our planet. The rapid growth of human population and the increasing pressure of civilization have led to greater human impact on nature. Due to the development of transport, tourism and trade, many plant and animal species have spread beyond their natural range. The colonization of new territories has been usually accompanied by breaking geographical and ecological barriers. Therefore it has become undesirable, because aside from lack of benefits, it often brings a risk of disturbance to local evolutionarily stable biocenoses (Pimentel 2002). In some cases it can have catastrophic results for local taxa, mainly when it comes to competition for food, space, light and other environmental resources. When this process is accompanied by a decrease in the biodiversity of ecological groups, we are dealing with a biological invasion (Richardson et al. 2000).
In recent years biological invasions have became serious a ecological and socio-economic problem for many countries. Annual losses of global economy resulting from biological invasions are estimated at 1.4 trillion dollars (Pimentel 2002). The enormous scale of this problem was the reason for presenting it at the World Summit on Sustainable Development, WSSD in Johannesburg (2002). It is also a major threat to world biodiversity (Baskin 2002). Increasing deliberate and accidental introductions of alien species, as well as their increasing harmfulness, is responsible for the escalation of this phenomenon (Solarz 2007). The reasons for the increase of invasiveness can be found in the poor management of natural resources and the low resistance of ecosystems (McNeely et al. 2001; Wittenberg $\&$ Cock 2001). Aquatic ecosystems are the best example of it, since they are weakened by pollution, extensive resource exploitation and progressive eutrophication. The unfavorable conditions for the development of stenotopic species leads to their elimination and provides an ecological niche for eurytopic taxa more tolerant of changing environmental 
conditions. They include numerous species of Amphipoda and fish (Pisces), which gradually expand their range. The DAISE research program (Delivering Alien Species Inventories for Europe) has demonstrated the existence of more than 11000 foreign taxa in Europe, of which about 1/3 are animals. Among them are the most dangerous invasive species in Poland, i.e. Round goby Neogobius melanostomus, Topmouth Gudgeon Pseudorasbora parva, Louisiana crawfish Procambarus clarkia, Fish-hook Waterflea Cercopagis pengoi, Zebra mussel Dreissena polymorpha, Asian Clam Corbicula fluminea, Warty Comb Jelly Mnemiopsis leidyi.

\subsection{The causes and means of spreading the invasion in aquatic ecosystems}

The direct cause of the intensification of the phenomenon of biological invasion in the last century has been the strong development of water transport and the increase in trade. The construction of new canals linking rivers has contributed to the elimination of already existing bio-geographical barriers, thus allowing the migration of organisms. The seas of southern Europe (Caspian, Azov, Black, Mediterranean) have become linked with northern part of Europe seas (Baltic, North Sea), creating corridors for alien species (Bij de Vaate et al. 2002; Ketelaars 2004; Galil et al. 2007). In this way the waters of central and western Europe have been penetrated by some fish species, as well as mollusks and crustaceans from the Ponto-Caspian region. Especially expansive have been fish from The Gobiidae family ( $\mathrm{Ne}$ ogobius melanostomus, N. gymnotrachelus, N. kessleri, N. fluviatilis, Proterorhinus marmoratus), amphipods from Gammaridae family (Dikerogammarus villosus, Gammarus tigrinus, Pontogammarus robustoides), mollusc Dreissena polymorpha and cladocera Cerophagis pengoi (Konopacka 2004; Kostrzewa et al. 2004; Jażdżewski et al. 2002, 2004; Gruszka 1999; Leppäkoski \& Olenin 2002; Grabowski et al. 2007; Bącela et al. 2008).

One major contribution to the movement transfer of species outside their natural range has been the development of international shipping. Researchers estimate that on a global scale 3 to 4 thousand species are transferred in one day in ships' ballast water. These species often travel long distances and are released hundreds or thousands kilometers from home. This is how Warty Comb Jelly Mnemiopsis leidyi entered Europe (Shiganova et al. 2001a).

Another reason for the spread of the invasion has been the stocking of reservoirs with alien species and material from other basins. This deliberate action is often financially motivated and does not take threats in to account. Mainly species with economic importance are introduced. Examples of species which were deliberately introduced to Europe are: Brown trout Salmo trutta, Brown Bullhead Ameiurus nebulosus and Prussian carp Carrasius auratus gibelio. It happens that with stocking material undesirable species are introduced, i.e.: Topmouth gudgeon Pseudorasbora parva, which was brought to European waters along with fry of Asiatic cyprinid fish (Grabowska et al. 2008). Intentional introductions also apply to some crustaceans, such as Louisiana crayfish Procambarus clarkia or Signal crayfish Pacifastacus leniusculus, which were brought to Europe from North America (Holdich 2000; Gherardi 2006).

On a smaller scale there have been invasions as a result of fish escaping from farms or released by aquarists. Recently however, the number of tropical species even in Polish waters has increase (Grabowska et al. 2008).

The more favourable factors of biological invasion in aquatic ecosystems are: the increase in temperature, salinity and water pollution (Carlton 2000; Jażdżewski et al. 2002). Their action can be harmful to some native species, while benefitting alien species (Kostrzewa et al. 2004). It is worth mentioning, that aquatic ecosystems are more sensitive to abiotic agents than terrestrial ecosystems, and therefore biological invasions there occur much more frequently (Sorte et al. 2010).

\subsection{Risk associated with invasion of alien species}

The appearance of alien species always confronts us with the problem of their impact on the ecosystem. In fact, only a small number of introduced species is able to settle down and reproduce. Even those who manage to overcome the reproductive barrier, are usually not a threat to native flora and fauna. The danger arises when alien species become too expansive and begin to adversely affect native wildlife.

The ecological consequences of a biological invasion might appear at different levels of life organization, ranging from genetic changes in population (Ayres et al. 2004), to changes in the functioning of local ecosystems (Meister et al. 2004; Albins \& Hixon 2008). Often those changes a have long-term character and the final outcome is difficult to predict. An excellent example is The Lake Victoria situation, connected with introduction of Nile perch Lates niloticus in 1954. As a result of predator activity, within a decade over 200 endemic fish species have disappeared forever out of the lake (Barel et al. 1985; Craig 1991) and the ecosystem of the lake has radically changed (Bwanika et al. 2006).

The degree of risk associated with biological invasions depends largely on the interaction between alien and native species (e.g. competition, predation, hybridizing). Usually allochthonous species compete with related indigenous species for food and space, thus they contribute to the displacement of native species from their natural habitat. Crustaceans are considered particularly dangerous competitors. As shown by Grabowski et al (2007) and Gruszka (1999) 
that not only can they gain numerical advantage over the native species, but they can also successfully replace them. Examples of water reservoir dominated by alien crustaceans species are the Vistula Lagoon, The Szczecin Lagoon and the Bay of Szczecin. There are many species like $D i$ kerogammarus haemobaphes, Pontogammarus robustoides and Gammarus tigrinus.

Another extremely expansive invertebrate, capable of mass colonization of European waters is the Warty Comb Jelly Mnemiopsis leidyi. History shows that the occurrence of this species in seas of the Ponto-Caspian region, especially in the Black Sea and the Caspian Sea, has resulted in an imbalance of ecosystems in both seas. The high density of the Warty Comb Jelly combined with its rapacity has contributed, decreased the abundance of planktonophagous fish and the predatory fish feeding on them (Shiganova 1997, 1998; Shiganova et al. 2001a, 2001b). Fishery losses caused by the decline of the number of beluga sturgeon (Huso huso) are estimated at about 500 million dollars annually.

The Fish-hook waterflea Cerophagis pengoi may have a similar effect on aquatic ecosystems. According to some research, the mass appearance of this shellfish in the waters of central Europe (including the Baltic Sea) has contributed to the decline of fish stock, as well as significantly reduced the number of other predatory species of Cladocera (Kotta et al. 2006) and copepods (Lehtiniemi \& Gorokhowa 2008).

As well as crustaceans, large expansiveness is characteristic of some alien fish species including Round goby. Over the last thirty years, this species has successfully populated the coastal areas of European seas, i.e. the Baltic Sea and North Sea. As an aggressive predator it competes with native fish species for food and habitat, thus it may contribute to the reduction of local fish stocks (Sapota \& Skóra 2000; Corkum et al. 2004).

A major threat to the biodiversity of aquatic ecosystems is the hybridization of alien species with native species. Especially susceptible to hybridization are fish which do not have sufficient mechanisms for reproductive isolation (Olden et al. 2004). As a result, hybrids, which might gain advantage over native species, are formed and increase the success of the invasion. Such a situation occurred after the introduction of Brook trout Salvelinus fontinalis to reservoirs with native Brown trout Salmo trutta (MacCrimmon \& Campbell 1969). Crossing between both species of trout produced sterile hybrids, as a result the population of native Brown trout decreased rapidly. Similarly, the introduction of European Rainbow trout to the rivers of the United States has resulted in the loss of a distinct gene pool of salmonids, with the result that five species are in danger of extinction (Olden et al. 2004).

The negative impact of alien species results also from the fact they are a potential source of many diseases, to which native species are not resistant (Dobson \& Fou- fopoulos 2001; Vignon \& Sasal 2007). Those are largely parasitic diseases, causing significant losses in the fry of native species (Pojmańska \& Chabros 1993). a prime example is the situation associated with the introduction of Baltic salmon infected with Gyrodactylus salaris to Norwegian waters with Atlantic salmon. The translocation of the parasite to Atlantic salmon fry has resulted in the death of $90 \%$ of juveniles and almost the total disappearance of adults individuals (Johnsen \& Jensen 1991). a similar case has occurred in North America where, along with nonnative salmonidae Myxobolus cerebralis was introduced (Bartholomew \& Reno 2002). As a result, the population of hosts rapidly decreased.

Invasions of Asian fish have become particularly dangerous for native aquatic ecosystems in recent years. The introduction to European waters of Pseudorasbora parva, Anguilla japonica, or Ctenopharyngodon idella, has contributed to the spread of many parasites. The following species have been brought: Spherotecum destruens (Gozlan et al. 2005), two tapeworms of cyprinids Bothriocephalus acheilognathi and Khawia sinensis (Pojmańska \& Chabros 1993), or attacking eesl nematode Anguilicola crassus (Morozińska-Gogol 2005). Theirs presence can cause great damage, mainly in fish farms.

Beside fishes, crustaceans are also important vectors of foreign pathogens. These include invasive species of crayfish and crabs, which have colonized water reservoirs across Europe. One of them is Louisiana crayfish Procambarus clarkii. As a vector of a dangerous fungus Aphanomyces astci, which causes the crayfish fungus plague, which is a serious threat for native European crayfish. It is also a host to flukes of the genus Paragonimus, which are potentially dangerous to human, therefore limiting its coverage is very important (Choi \& Hwang 1980).

These examples show only some of the effects of biological invasion. Regardless the scale of the problem they are a serious threat for biodiversity, health and economy.

\section{Summary and conclusions}

This data shows that biological invasions are a particular case of settling up an organism outside its natural range. Invasions are promoted by anthropogenic activity which is broadly understood, as well as the instability of ecosystems. It carries a number of threats, which are often difficult to predict. The effects of invasion are long-term and occur on many levels of life. Very often they can contribute to the extinction of native species, thus reducing biodiversity.

Sustainable development, the protection of biodiversity and the prevention of biological invasions, is the necessary to maintain the variety of nature, and to further the economic development of each country. There are a number of 
legislative provisions governing the prevention of the introduction of alien species. As those provisions do not fully protect from invasions, constant monitoring of aquatic ecosystems state is important. This allows the fast identification of threats and appropriate action. An other important element in the fight against biological invasions is the increasing environmental awareness in society. The problem of biological invasions is usually underestimated due to the lack of obvious economic loss. In some cases the presence of alien species is seen in terms of profit and financial benefit (fish trade, aquaculture). That is why social campaigns which reflect the effects of biological invasions for the economy and environment are so important.

\section{References}

Albins, M. A. \& Hixon M. A., 2008, Invasive Indo-Pacific lionfish Pterois volitans reduce recruitment of Atlantic coral-reef fishes, Marine Ecology Progress Series 367: 233-238.

Ayres D. R., Smith D. L., Zaremba K., Klohr S. \& Strong D. R., 2004, Spread of exotic cordgrasses and hybrids (Spartina sp.) in the tidal marshes of San Francisco Bay, California, USA, Biological Invasions 6: 221-231.

Barel, C. D. N., Dorit R., Greenwood P. H., Fryer G., Hughes N., Jackson P. B. W., Kawanabe H. \& LoweMcConnell R. H., 1985, Destruction of fisheries in Africa's Lakes, Nature 315: 19-20.

Bartholomew J. L. \& Reno P. W., 2002, The history and dissemination of whirling disease, [in:] J. L. Bartholomew, J. C. Wilson (eds.), Whirling disease: reviews and current topics, American Fisheries Society, Bethesda: 3-24.

Bącela K., Grabowski M. \& Konopacka A., 2008, Dikerogammarus villosus (Sowinsky, 1894) (Crustacea, Amphipoda) enters Vistula - the biggest river in the Baltic basin, Aquatic Invasion 3 (1): 95-98.

Bij de Vaate A., Jażdżewski K., Ketelaars S., Gollasch S. \& Van der Velde G., 2002, Geographical patterns in range extension of Ponto-Caspian macroinvertebrate species in Europe. Perspective, Canadian Journal of Fisheries and Aquatic Sciences 59: 1159-1174.

Baskin Y., 2002, a plague of rats and rubbervines, Island Press, Shearwater Books, Washington, London.

Bwanika G. N., Chapman L. J., Kizito Y. \& Balirwa J., 2006, Cascading effects of introduced Nile perch (Lates niloticus) on the foraging ecology of Nile tilapia (Oreochromis niloticus), Ecology of Freshwater Fish 15: $470-481$.

Carlton J. T., 2000, Global change and biological invasions in the oceans, [in:] H. A. Mooney, R. J. Hobbs (eds.), Invasive species in a changing world, Island Press, Washington, USA: 31-53.

Choi D. W. \& Hwang J. T., 1980, Epidemiological study of Paragonimus westermani in Wiseong County, Kyung- pook Province, Korea, Korean Journal of Parasitology 18 (2): 229-234.

Corkum L. D., Sapota M. R. \& Skóra K. E., 2004, The round goby, Neogobius melanostomus, a fish invader on both sides of the Atlantic Ocean, Biological Invasions 6: 173-181.

Craig J. F., 1991, Human-induced ges in the composition of fish communities in the African Great Lakes, Reviews in Fish Biology and Fisheries 2: 93-124.

Dobson A. \& Foufopoulos J., 2001, Emerging infectious pathogens of wildlife, Philosophical Transactions of the Royal Society London B 356: 1001-1012.

Galil B. S., Nehring S. \& Panov V., 2007, Waterways as invasion highways - Impact of climate change and globalization, Ecological Studies, Springer Verlag 193: 59-74.

Gherardi F., 2006, Crayfish invading Europe: the case study of Procambarus clarkii, Marine and Freshwater Behaviour and Physiology 39 (3): 175-191.

Gozlan R. E., St-Hilaire S., Feist S. W., Martin P. \& Kent M. L., 2005, Disease threat to European fish, Nature 435: 1046.

Grabowski M., Jażdżewski K. \& Konopacka A., 2007, Alien Crustacea in Polish waters - Amphipoda, Aquatic Invasion 2 (1): 25-38.

Grabowska J., Witkowski A. \& Kotusz J., 2008, Inwazyjne gatunki ryb w polskich wodach - zagrożenie dla rodzimej ichtiofauny [Invasive fish species in Polish waters - the threat to native ichthyofauna], Użytkownik rybacki - Nowa rzeczywistość, PZW: 90-96.

Gruszka P., 1999, The River Odra Estuary as a Gateway for Alien Species Immigration to the Baltic Sea Basin, Acta Hydrochimica et Hydrobiologica 27: 374-382.

Holdich D. M., 2000, The introduction of alien crayfish species into Britain for commercial exploitation - an own goal? Crustacean Issues 12: 85-97.

Jażdżewski K., Konopacka A. \& Grabowski M., 2002, Four Ponto-Caspian and one American gammarid species (Crustacea, Amphipoda) recently invading Polish waters, Contributions to Zoology 71 (4): 115-122.

Jażdżewski K., Konopacka A. \& Grabowski M., 2004, Recent drastic changes in the gammarid fauna (Crustacea, Amphipoda) of the Vistula River deltaic system in Poland caused by alien invaders, Division Distribution 10: 81-87.

Johnsen B. O. \& Jensen A., 1991, The Gyrodactylus story in Norway, Aquaculture 98: 289-302.

Ketelaars H. A. M., 2004, Range extensions of Ponto-Caspian aquatic invertebrates in continental Europe, [in:] H. J. Dumont, T. A. Shiganova, U. Niermann (eds.), Aquatic Invasions in the Black, Caspian, and Mediterranean Seas, Kluwer Academic Publishers: 209-236.

Konopacka A., 2004, Inwazyjne skorupiaki obunogie (Crustacea, Amphipoda) w wodach Polski [Invasive amphipods (Crustacea, Amphipoda) in Polish waters], Przegląd Zoologiczny 48: 141-162. 